DOI: https://doi.org/10.47405/mjssh.v6i10.1118

\begin{tabular}{|c|c|}
\hline 4.581 & Malaysian Journal of Social Sciences and Humanities (MJSSH) \\
\hline $\begin{array}{l}\text { Malaysian Journal of } \\
\text { Social cciences and }\end{array}$ & Volume 6, Issue 10, October 2021 \\
\hline (MJ-SSH) & e-ISSN : 2504-8562 \\
\hline & $\begin{array}{l}\text { Journal home page: } \\
\text { www.msocialsciences.com }\end{array}$ \\
\hline
\end{tabular}

\title{
Perceived Organizational Support and Teacher Motivation
}

\author{
Connie Cassy Ompok ${ }^{1}$, Lydia Teo $^{2}$ \\ 1Faculty of Psychology and Education, Universiti Malaysia Sabah (UMS), Malaysia \\ 2Institut Pendidikan Guru Kampus Keningau, Sabah, Malaysia \\ Correspondence: Connie Cassy Ompok (connieompok@ums.edu.my)
}

\begin{abstract}
Rural schools that lack of basic facilities and infrastructure is the focus of the study. With this ruralism conditions, teachers in rural primary school face many obstacles and challenges that could hinder their motivation. These might affect their teaching effectiveness. This study was intended to determine perceived organisational support on teacher motivation. The research sample consisted of 138 teachers in Sabah that directly become the respondents of the study. Data was obtained via questionnaire which was consisted of perceived organisational support: 17 items; and teacher motivation: 5 items). With success rate of $74 \%$ returned questionnaire and 102 fit to be evaluated, the data revealed that there was a strong correlation between perceived organisational support on teacher motivation. Teachers should be given support in order to enhance or maintain their motivation especially in rural condition.
\end{abstract}

Keywords: perceived organizational support, teacher motivation, rural schools

\section{Introduction}

Human capital development is the main key factor to achieve Malaysia's Vision and it needs the attention from both government and private sectors. Human capital is the most important asset that any organisation can posses. Rapid development in the country that contributed to the needs of more competent human resources has brought the changes to the education sector. In realizing this, the government of Malaysia through the Ministry of Education has made tremendous efforts to uplift the standard of education in rural areas.

Ministry of Education has proactively committed to develop rural human resources by assigning more qualified and experienced teachers to rural area. Apart from that, the government also has upgraded the school facilities for the convenience of both teachers and students. As a teacher, they should always be ready to educate the pupils without considering the limitation factors persist at the schools. This is because human capital development should begin during earlier education stages in the primary schools either in urban or rural areas. In the digital era and look at its impact since schools will remain closed for long periods, the federal government may consider to upgrade or rebuild the dilapidated schools in Sabah so they can be environments that are more conducive to teaching and learning. Wellbeing of the teachers was in turn predictive of lower motivation to leave the profession and higher engagement (Skaalvik \& Skaalvik, 2018).

Consequently, the purpose of this study was to examine the relationship between the education management and teachers represented by perceived organisational support and teacher motivation. 


\section{Literature Review}

\section{Perceived organisational support}

Eisenberger et al. (1986) defined perceived organisational support as individuals global beliefs about the extend to which the organisation cares about their well-being and to which it values their contribution. The government has allocated RM50.4 billion for schools and education, or $15.6 \%$ of total government to support education in the country as announced in Post Budget 2021. This indicated that the teachers had been given perceived organisational support by the government. Somehow, does this perceived organisational support will lead to the increase of teacher motivation to teach and serve longer in rural school? Not only that, the availability of perceived organisational support also assured that the support will always be ready as needed by the employees when the support is in need Eisenberger et al. (1997). Supports are in needs by the teachers when they are in difficult situation to overcome certain tasks or deal with harsh situation. This is more important in rural school where lack of facilities and getting assistance from other outside resources are very restrictive. In addition, Eisenberger et al. (1990) suggested that employees would consider perceived organisational support as discretionary activities by the organisation that benefited them as evidence that the organisation cared about their well-being.

\section{Motivating potential}

Hackman and Oldham (1975) sought to measure the motivating potential of jobs. In other words, to measure the extent that a job exhibits the five characteristics listed such as skill variety, task identity, task significance, autonomy and feedback. Skill variety the exercise of a number of different skills, abilities or talent. Task identity to which a job requires completion of a whole and identifiable piece of work. Task significance refers to the importance of the job. Autonomy is the degree to which the jobholder is free to schedule the pace of his or her work and determine the procedures to be used. Feedback is the degree to which the individual doing a job obtains information about the effectiveness of the performance. Feedback refer to supervisory feedback, but also the ability to observe the results of their work.

A motivating job (a high Motivating Potential Score) showed evidence of all five-core characteristics. Skill variety, task identity and task significance all serve to account for a sense of meaningfulness. A job with autonomy serves give the jobholder a sense of responsibility, while feedback satisfies the need for knowledge. The study done by Pourtousi and Ghanizadeh (2020) demonstrated that English as a foreign language EFL teachers' motivation positively and significantly predicted work engagement and job commitment. Jaafar and Salim (2017) conduct a study to examine the relation between performance appraisal and motivation of teachers in the district of Sabak Bernam. They found that there are significant relations in positive between aspects of performance appraisal and motivation of teachers. In another study done by Sulaiman et al. (2021), they found that the e-evaluation, stress and work motivation of teachers during the MCO were conducted at a moderate level. These studies showed that guidance and support given in schools are important.

\section{The relationship of perceived organisational support on teacher motivation}

Perceived organisational support has been proved to have important consequences on employee performance and well-being that associate with employees' motivation. Eisenberger et al. (1986) stated that perceived organisational support is about the individual's global beliefs on their well-being and to which organisation values their contribution. According to Rhoades and Eisenberger (2002), organisational theory also addresses the psychological processes underlying consequences of perceived organisational support. They described that perceived organisational support should produce a felt obligation to care about the organisation's welfare and to help the organisation reach its objectives, this followed by the caring, approval and respect connoted by perceived organisational support that would fulfil socio-emotional needs. 
Perceived organisational support resulted on favourable outcomes that benefits both employees (e.g. motivation and satisfaction) as well as organisation (e.g. increased affective commitment, reduced turnover, retaining top employee). Perceived organisational support has important implication on teacher motivation as on other employees. Consistent with the view that employees form a general belief regarding the organisation's commitment to them. Eisenberger et al. (1986) reported that employees showed a consistent pattern of agreement with statements concerning whether the organisation appreciated their contributions and would treat them favourably or unfavourably in different circumstances. Relationships and school contexts affect teacher efficacy (Hsieh, Liao \& Lee, 2020).

\section{Research Methodology}

\section{Research design}

The study involved descriptive study method designed using cross-sectional data. The research sample consisted of 138 teachers in Sabah that directly become the respondents of the study.

\section{Instrument Design}

This study adopted the quantitative method that utilized questionnaire for the means of data collection. The questionnaire personally administered to the headmasters of the school through Education Office for easing the process of obtaining the feedback from the respondents.

\section{Questionnaire Outline}

The response to the items is captured on a 5-point scale showed as Table 1 . The questions were positively and negatively worded using Likert scale scoring method, consisted of 5 point scale, ranged from 1 , which is, very dissatisfied, 2 is dissatisfied, 3 is undecided, 4 is satisfied and 5 is very satisfied (Sekaran, 2004).

Table 1: 5-point scale response on independent and dependent variables

\begin{tabular}{lllll}
\hline $\mathbf{1}$ & $\mathbf{2}$ & $\mathbf{3}$ & $\mathbf{4}$ & $\mathbf{5}$ \\
\hline Very dissatisfied & Dissatisfied & Undecided & Satisfied & Very satisfied \\
\hline
\end{tabular}

\section{Perceived organisational support}

Eisenberger et al. (1986) developed a scale with 36 items form for Survey of perceived organisational support and also a shorter versions (e.g. Armeli et al., 1998; Eisenberger et al., 1990; Lynch et al., 1999; Shore \& Tetrick, 1991; Shore \& Wayne, 1993). Further, the author employed shorter version of perceived organisational support that consisted of 17 -items. This is because most of studies on perceived organisational support used a short form version developed from the 17 highest loading items in the perceived organisational support Eisenberger et al. (1986). Questions included "The education management values my contribution to the school well-being"; "The education management fails to appreciate any extra effort from me"'(Reverse question); "The education management strongly consider my goals and values"; "The education management would ignore any complaint from me" (Reverse question); "The education management disregards my best interests when it makes decisions that affect me" (Reverse question); "Help is available from the education management when I have a problem"; "The education management really cares about my well-being"; "Even if I did the best job possible the education management would fail to notice" (Reverse question); "The education management is willing to help me when I need a special favour"; "The education management cares about my general satisfaction at work"; "If given the opportunity the education management would take advantage of me" (Reverse question); "The education management shows very little concern for me" (Reverse question); "If I decided to quit the education management would try to persuade me to stay"; "The education management cares about my opinions"; "The 
education management takes pride in my accomplishments at work"; "The education management tries to make my job as interesting as possible" and "The education management proud that I am a part of this organisation". Reverse question that are negatively worded were changed to positively worded items when conducting the statistical analysis. Questions must be coded into one direction.

\section{Sampling Design}

Teachers who were eligible for receiving hardship allowances due to the criteria established became the respondents of this study.

\section{Data Collection Method}

This study involved cross-sectional data gathering approaches whereby the questionnaires developed were disseminated only once. The questionnaire was given to respective teachers through their headmasters. The teachers were required to fill in the questionnaire within 3 weeks and needs to be submitted to their respective headmasters. Then, the answered questionnaires further delivered to the author by the headmasters.

\section{Data Analysis}

Data collected were analyzed by using Statistical Package of the Social Sciences (SPSS version 13) to measure relationship or correlation between independent variable and dependent variable. Regression analysis was used primarily for the purpose of prediction. The author has developed a regression model to predict the values of a dependent or response variables based on the values of one explanatory or independent variables. Regression analysis was used when independent variables are correlated with one another and with dependent variables. In this study, there are two types of regression analysis that were employed.

\section{Research Findings}

\section{Perceived Organisational Support}

The respondents' respond on the 17 items of perceived organisational support were showed in Table 2.

Table 2: Cross tabulation of the respondents' response on each 17 items of perceived organisational support ( $\mathrm{N}=98)$

\begin{tabular}{|c|c|c|c|c|c|c|}
\hline \multirow[t]{2}{*}{ ITEMS } & \multicolumn{5}{|c|}{ Respondents Percentage (\%) } & \multirow[t]{2}{*}{ S.D } \\
\hline & VD & D & $\mathbf{U}$ & $\mathbf{S}$ & VS & \\
\hline $\begin{array}{l}\text { The education management values my contribution } \\
\text { to the school well-being. }\end{array}$ & 0 & 1 & 39.2 & 31.4 & 28.4 & 0.84 \\
\hline $\begin{array}{l}\text { The education management always appreciates any } \\
\text { extra effort from me. }\end{array}$ & 0 & 2.9 & 32.4 & 54.9 & 9.8 & 0.680 \\
\hline $\begin{array}{l}\text { The education management strongly considers my } \\
\text { goals and values. }\end{array}$ & 0 & 11.8 & 34.3 & 26.5 & 27.5 & 1.003 \\
\hline $\begin{array}{l}\text { The education management would consider any } \\
\text { complaint from me. }\end{array}$ & 1 & 5.9 & 25.5 & 40.2 & 27.5 & 0.919 \\
\hline $\begin{array}{l}\text { The education management regards my best } \\
\text { interests when it makes decisions that affect me. }\end{array}$ & 0 & 7.8 & 42.2 & 38.2 & 11.8 & 0.804 \\
\hline $\begin{array}{l}\text { Help is available from the education management } \\
\text { when I have a problem. }\end{array}$ & 0 & 10.8 & 28.4 & 37.3 & 23.5 & 0.943 \\
\hline $\begin{array}{l}\text { The education management really cares about my } \\
\text { well-being. }\end{array}$ & 0 & 2.9 & 36.3 & 32.4 & 28.4 & 0.868 \\
\hline If I did the best job possible, the education & 0 & 5.9 & 28.4 & 43.1 & 22.5 & 0.849 \\
\hline
\end{tabular}


management would always to notice.

The education management is willing to help me when I need a special favor.

The education management cares about my general satisfaction at work.

If given the opportunity, the education management would not take advantage of me.

The education management shows very much concern for me.

If I decided to quit, the education management would try to persuade me to stay.

The education management cares about my opinions.

The education management takes pride in my accomplishments at work.

My education management tries to make my job as interesting as possible.

$\begin{array}{lllllll}\text { My education management is proud that I am a } & 0 & 0 & 36.3 & 19.6 & 44.1 & 0.898\end{array}$ part of this organisation.

Note: VD = Very dissatisfied; $\mathrm{D}=$ Dissatisfied; $\mathrm{U}=$ Undecided; $\mathrm{S}=$ Satisfied; VS = Very satisfied; $\mathrm{SD}=$ Standard Deviation

This result was based on the total respondents view without considering their background. Generally, majority of the total respondents are very satisfied that, the education management proud that teachers are part of this organisation (item 17,44.1\%), if the teachers did the best of job possible, the education management would notice (item 7, 28.4\%), values their contribution (item 1, 28.4\%), strongly consider their goals and values (item $3,27.5 \%$ ) and the education management would notice any complaint from the teachers (item 4, 27.5\%). Further, this result showed that if given the opportunity, the education management would not take advantage of the teachers (item15, 15.7\%), the education management regards the teachers interest when it makes decisions that effect them (item 5, 11.8\%) and the education management appreciate any extra effort from the teachers (item 2, 9.8\%).

\section{Hypotheses Testing Using Simple Linear Regression}

This part presents the test and explanation of the hypotheses, which derived for this research. The results of the hypotheses tested are as the following. The first regression analysis is simple Linear Regression which a statistical techniques that uses a single numerical. The independent variables $X$ (perceived organisational support) was used to predict the numerical dependent variable Y (teacher motivation).

\section{Hypotheses 1: There is a significance relationship between perceived organisational supports on teacher motivation.}

Perceived organisational support is entered into simple linear regression model with teacher motivation as the dependent variable. From the study, it showed that there is a significant correlation between perceived organisational support and teacher motivation at 5\% significant, $\mathrm{F}=98.231$ distribution shown the existence of a model. The result of these relationship are presented in Table 3. 
Table 3: Statistical summary for the regression between perceived organisation support and teacher motivation

\begin{tabular}{|c|c|c|c|c|c|c|c|c|}
\hline Model & $\mathbf{R}$ & $\begin{array}{l}\text { R } \\
\text { Square }\end{array}$ & $\begin{array}{l}\text { Adjusted } \\
\text { R } \\
\text { Square }\end{array}$ & $\begin{array}{l}\text { Std. Error } \\
\text { of the } \\
\text { Estimate }\end{array}$ & \multicolumn{3}{|c|}{ Change Statistics } & $\begin{array}{l}\text { Durbin- } \\
\text { Watson }\end{array}$ \\
\hline & & & & & $\mathrm{R}$ & & Sig. F & \\
\hline & & & & & Square & $\mathrm{F}$ & Chang & \\
\hline & & & & & Change & Change & & \\
\hline & 0.704 & 0.496 & 0.490 & 0.393 & 0.496 & 98.231 & 0.000 & 1.726 \\
\hline
\end{tabular}

Table 4: Coefficients table for perceived organisational support and teacher motivation.

\begin{tabular}{llllll}
\hline Model & \multicolumn{2}{l}{$\begin{array}{l}\text { Unstandardized } \\
\text { Coefficients }\end{array}$} & $\begin{array}{l}\text { Standardized } \\
\text { Coefficients }\end{array}$ & t & Sig. \\
\hline & B & Std. Error & Beta & & \\
& 0.563 & 0.339 & & 1.661 & 0.100 \\
& 0.882 & 0.089 & 0.704 & 9.911 & 0.000 \\
\hline
\end{tabular}

The result of the simple linear regression analysis in Table 3 and 4 showed that at $F=98.23$ and $p$ $=0.000$ (less than 0.05 ) perceived organisational support (independent variable) significantly related to teacher motivation. While $\mathrm{t}=9.911$, and $\mathrm{p}=0.000$ (less than 0.05 ), indicated that perceived organisational support significantly determines the teacher motivation. Durbin-Watson value of 1.726 indicates that perceived organisational support was significant on teacher motivation. The coefficient of determination $\mathrm{R}^{2}$ for this model is 0.496 indicating that $49.6 \%$ of the variation in teacher motivation (dependent variable) is explained by the perceived organisational support (independent variable). In other words, perceived organisational support predicts a significant percentage on teacher motivation. Meaning, $50.4 \%$ of the variation in teacher motivation could be determined by the others factors besides perceived organisational support.

From Table 4.8, the constant ( $\mathrm{Y}$ intercept), $\beta 0=0.563$ and $\beta 1=0.882$, so the linear equation can be written as follows,

$Y=0.563+0.882 X$,

Where:

$\mathrm{Y}=$ Teacher motivation (dependent variable)

$\mathrm{X}=$ Perceived organisational support (independent variable)

$Y$ intercept, $\beta 0=0.563$

Slope, $\quad \beta 1=0.882$

The $Y$ intercept, $\beta 0=0.563$ indicated that when the percentage of perceived organisational support is at 0 , the expected change in teacher motivation is $0.563 \%$. The $\beta_{1}=0.882$ indicates that for each $1 \%$ increased in perceived organisation support, it is predicted an increased of $+0.882 \%$ on teacher motivation. From this equation, it is concluded that there is significant positive linear relationship between perceived organisational support and teacher motivation. Therefore, hypotheses 1 is accepted.

\section{Conclusion}

Teacher motivation is the result of many inter-related factors. Some teachers in rural schools always felt motivated and some are less motivated. The source of their motivation are various between the teachers of different background and school conditions (management, infrastructure, facilities). Teachers in rural primary school generally wanted to be effective, explore new challenges and engage in ongoing personal and professional development. As known by all, people are always active by nature and driven to continually adapt to changes in the environment in order to be successful. 
Somehow, if the individual is not in phase or parallel with the environment, he or she will be hindered from achieving success and be less motivated which will reduce their job effectiveness. Generally, teachers tend to give their best for the school that give them something in return (Kushman, 1992). It could be from the students and from the school either in the form of intrinsic as well as extrinsic. These could be in the form of rewards and supports that could satisfy their intrinsic needs.

Further, as noted by Northwest Regional Educational Library (2001), motivation could not be done to someone and it cannot be controlled or commanded into being. Motivation is a complex human dynamic that can only be understand and work to inspire the being. Hence, for rural teachers, understanding their antecedent of their motivation would help to inspire their motivation as well as other teachers in rural school on managing rural teacher motivation.

Teacher by profession is a committed employee. For those teachers that assigned in rural school that lack of infrastructure, facilities and far from township, their commitment towards their task might be degraded. In rural area typically where the school environment is always in dire straight with lacking of teaching facilities, unconducive working and staying environment for the teacher and student, motivation is the only elements that can overcome these obstacles. Hence, their utmost motivation is always in need in order to make learning more interesting and enjoyable for the benefit of the student.

The study revealed that perceived organisational support has significant relationship on teacher motivation. This means perceived organisational support is crucial to maintain or strengthen the rural teacher's motivation. Reduction in perceived organisational support will contribute to the reduction of the teacher personal motivation. Continuous and deliberate support from the education management will strengthen teachers motivation in the rural school. As Eisenberger et al., (1986) noted on perceived organisational support, once the organisation or employer fulfilled the employee expectation that their organisation were concern and value their contribution; the employees will be motivated to perform their assigned task. As most remarked by the respondents on the 17 listed items, they did satisfied on the perceived organisational support that they received from the education management. For example, on item number 2 (The education management always appreciates any extra effort from me), remarked satisfied by $54.9 \%$ of the respondents. This proved that most of the education management in the rural area do appreciate any extra effort made by their teacher. This also constant with other item such as item $4,8,9,12,14$ and 16 that were remarked satisfied by more then $40 \%$ of the total respondents. These items of perceived organisational support refer to the situation that the education management would consider any complaint made by the teacher. Apart from that, education management always aware or concern about the performance, always providing assistance, concerned and taking note of their opinion.

Supportive headmaster, recognized as part of the organisation and being appreciate or regards for their contribution were among the perceived organisational support that the individual teacher needs to be motivated as showed by this study. With this perceived organisational support, the de-motivating pressure arose from being rural could be overcome by the teacher. When the psychological needs of the rural teacher met, they are more likely to direct their own growth and remain engaged in ongoing improvement. As showed in most case on motivation, when supported by the right conditions, people usually seek ongoing development (Bastick, 2000). Additionally, teacher will be motivated if they did not feel pressured and if their own feelings or points of view were acknowledged (Eghrari \& Deci, 1989). As other employee, teachers as well have a basic psychological need that should be met to be effective with what interests them and this need prompts us to internalize external demands that contribute to their end.

Of all the items tested, there are also some item that remarked 'unsatisfied' by majority of the respondents. These items were item 13, 'if I decided to quit, the education management would try to persuade me to stay' $53.9 \%$, item 5 , 'the education management regards my best interest when it makes decisions that effects me' $42.2 \%$, item 11 , 'if given the opportunity, the education management would take advantage on me $41.2 \%$. 
DOI: https://doi.org/10.47405/mjssh.v6i10.1118

On item number 7, it is not only the reliability of the headmasters solely to care about the well-being of their teachers. It is also the role of the government through the Ministry of Education to provide the physical infrastructure such as housing, allowances and other incentives for the teachers. This also indicated that $36.3 \%$ of the respondents in the rural primary still not satisfied of their basic physiological needs regarding their well-being. This could be on the aspects of conducive or safe living and working environment that lack in most of the rural school. Teacher's quarters, no electricity, small classrooms and some other unconducive conditions could inhibit or degrading the teacher motivation.

This study it has revealed that perceived organisational support did significantly correlated with the rural primary school teacher motivation. A school with good infrastructure and connectivity could hold back more teachers for more hours.

\section{References}

Armeli, S., Eisenberger, R., Fasolo, P., \& Lynch, P. (1998). Perceived organizational support and police performance: The moderating influence of socio-emotional needs. Journal of Applied Psychology, 83, 288-297.

Bastick, T. (2000). The measurement of teacher motivation: Cross-cultural and gender comparisons. Paper Presentation at the $29^{\text {th }}$ Annual Meeting of the Society of Cross-Cultural Research: New Orleans, Louisiana, USA.

Eghrari, H., \& Deci, E.L. (1989). Facilitating internalization: A motivational analysis. Unpublished manuscript, University of Rochester, NY.

Eisenberger, R., Cummings,J., Armeli, S. \& Lynch, P. (1997). Perceived organizational support. Journal of Applied Psychology, 82, 812-820.

Eisenberger, R, Fasolo, P., \& Davis-LaMastro, V. (1990). Perceived organizational support and employee diligence, commitment and innovation. Journal of Applied Psychology, 75, 51-59.

Eisenberger, R., Huntington, R., Hutchinson, S., \& Sowa, D. (1986). Perceived organization support. Journal of Applied Psychology, 71, 500-507.

Hackman, J.R., \& Oldham, G. R. (1975). Development of the Job Diagnostic Survey, Journal of Applied Psychology, 60, 159-170.

Hsieh, J.Y., Liao, P.W. \& Lee, Y.H. (2020). Teacher Motivation and Relationship Within School Contexts as Drivers of Urban Teacher Efficacy in Taipei City. Asia-Pacific Edu Res. https://doi.org/10.1007/s40299-020-00535-9

Lynch, P., Eisenberger, R., \& Armeli, S. (1999). Perceived organizational support: Inferior-versusSuperior Performance by Wary Employees. Journal of Applied Psychology, 84, 467-483.

Northwest Regional Educational Laboratory, (2001). Understanding motivation and supporting teacher renewal: Quality teaching and learning series. Editor: Jarrett-Weeks, D. Northwest Regional Educational Laboratory.

Rhoades, L., \& Eisenberger, R. (2002). Perceived organizational support: A Review of the

Sekaran, U. (2003). Study methods for business. A skill building approach, $\left(4^{\text {th }}\right.$ Edition): John Wiley \& Sons, Inc.

Jaafar, N. F. A., \& Salim, S. S. S. (2017). Teachers Motivation Towards Job Performance Appraisal Among Secondary School Teachers. International Journal of Academic Research in Business and Social Sciences, 9(7), 646-653.

Pourtousi, Z., \& Ghanizadeh, A. (2020) Teachers' Motivation and Its Association with Job Commitment and Work Engagement. Psychol Stud, 65, 455-466. https://doi.org/10.1007/s12646-020-00571-x

Shore, L.M., \& Tetrick, L.E. (1991). A construct validity study of survey of perceived organizational support. Journal of Applied Psychology, 76, 637-643.

Shore, L. M., \& Wayne, S.J. (1993). Commitment and employee behaviour: Comparison of affective commitment and continuance commitment with perceived organizational support. Journal of Applied Psychology, 76, 774-780. 
DOI: https://doi.org/10.47405/mjssh.v6i10.1118

Skaalvik, E.M., \& Skaalvik, S (2018) Job demands and job resources as predictors of teacher motivation and well-being. Soc Psychol Educ, 21, 1251-1275. https://doi.org/10.1007/s11218$\underline{018-9464-8}$

Sulaiman, T., Ibrahim, A., Motevalli, S., Wong, K.Y.\& Hakim, M.N. (2021), Effect of e-evaluation on work motivation among teachers during the movement control order in COVID-19: the mediating role of stress. Interactive Technology and Smart Education. https://doi.org/10.1108/ITSE-05-2020-0066 